\title{
Stereoselective Synthesis of Empenthrin, a Novel Insecticide against Fabric Pests, in a Regioselectively ${ }^{14} \mathrm{C}$-Labeled Form
}

\author{
Hiroshi Kanamaru, Kazuo Kawahara and Kazuhiko Nishioka \\ Biochemistry and Toxicology Laboratory, Takarazuka Research Center, \\ Sumitomo Chemical Co., Ltd. \\ 4-2-1, Takatsukasa, Takarazuka-shi, Hyogo-Pref. 665, Japan \\ Received November 5, 1990
}

\begin{abstract}
Two stereoisomers of empenthrin, (E)-1-ethynyl-2-methyl-2-pentenyl (1R)-cis, transchrysanthemates, were regioselectively labeled with carbon-14 for use in metabolic studies on the characteristic ethynyl alcohol moiety. Action of ethyl $\left[{ }^{14} \mathrm{C}\right]$ formate (2) on ethylidenetriphenylphosphorane gave the ${ }^{14} \mathrm{C}-$ formylated phosphorane (3). Wittig reaction of 3 with propanal stereoselectively yielded the $E$ isomer of $2-m e t h y l-2-\left[1-{ }^{14} \mathrm{C}\right]$ pentenal $(4)$, which was derivatized to a crystalline imidazolidine (5) for purification. Regeneration of 4 from purified 5 followed by reaction with ethynylmagensium bromide gave $(E)-1$-ethynyl-2-methyl-2-[1- $\left.{ }^{14} \mathrm{C}\right]-$ pentenol (6), the $\alpha$-ethynyl alcohol of ${ }^{14} \mathrm{C}$-labeled empenthrin, in $36 \%$ overall radiochemical yield from 2. Esterification of 6 with (1R)-cis- and (1R)-trans-chrysanthemoyl chlorides afforded the corresponding optically active [pentenyl-1-14 $\mathrm{C}]$ empenthrins $(\boldsymbol{1} \boldsymbol{a}$ and $\mathbf{1} \boldsymbol{b})$ in good yields after chromatographic purification.
\end{abstract}

Key Words : carbon-14, empenthrin, pyrethroidal insecticide, optically active, (E)-2-methyl-2-pentenal, $(E)$-1-ethynyl-2-methyl-2-pentenol

\section{Introduction}

Empenthrin is a new pyrethroidal insecticide possessing remarkable efficacy against fabric insect pests together with low mammalian toxicity $^{1)-3)}$. The efficacy is considered to be mainly attributed to the characteristic structure of its alcoholic part and the high vapor pressure. This pyrethroid is an ester of chrysanthemic acid with a novel synthetic ethynyl alcohol partially imitating the rethrolone skeleton of naturally occurring pyrethroids. Concerning the stereochemistry-insecticidal activity relationship, it has been confirmed that the efficacy originates from two $(1 R)$ isomers (i.e., $(1 R)$-trans and $(1 R)$-cis isomers), similarly to other well-known chrysanthemates $^{4}$. Therefore, this chemical has been developed in the optically active form for practical use. In the course of development, it was required to clarify its metabolic fate for safety assessment, particularly regarding the characteristic alcohol part, by using radiolabeled compounds. This paper describes a unique method for stereoselective synthesis of the regioselectively ${ }^{14} \mathrm{C}$-labeled ethynyl alcohol of empenthrin and the preparation of two optically active pyrethroidal esters from it.

\section{Results and Discussion}

Figure 1 illustrates a retrosynthetic analysis of empenthrin for ${ }^{14} \mathrm{C}$-labeling at the alcoholic C-1 position, which seemed to be the most favorable labeling position for our metabolic studies.

Through the analysis, carbonyl-labeled $(E)$-2methyl-2-pentenal (I) was considered the key intermediate of the present radiosynthesis. In the previously developed synthesis of non-radioactive empenthrin, only the $E$ isomer of the unsaturated aldehyde (I) was efficiently prepared by using the convenient aldol condensation of propanal alone with subsequent rapid dehydration $^{2), 3)}$. This method was, however, unacceptable for our labeling work, because there was a possibility that the $\left[{ }^{14} \mathrm{C}\right]$ empenthrin synthesized by using the aldol method as shown in Fig. 1, from $\left[1{ }^{-14} \mathrm{C}\right]$ propanal (II) via the unsaturated aldehyde (Ia) labeled at both sides of the double bond, might simultaneously produce two kinds of radioactive metabolites 


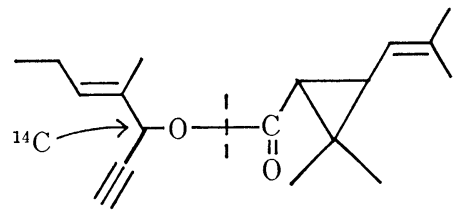

Empenthrin

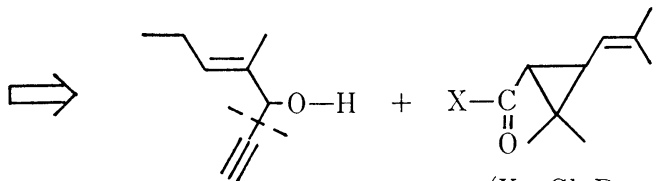

$(\mathrm{X}=\mathrm{Cl}, \mathrm{Br}$, etc. $)$<smiles>C1=CC=C1</smiles>

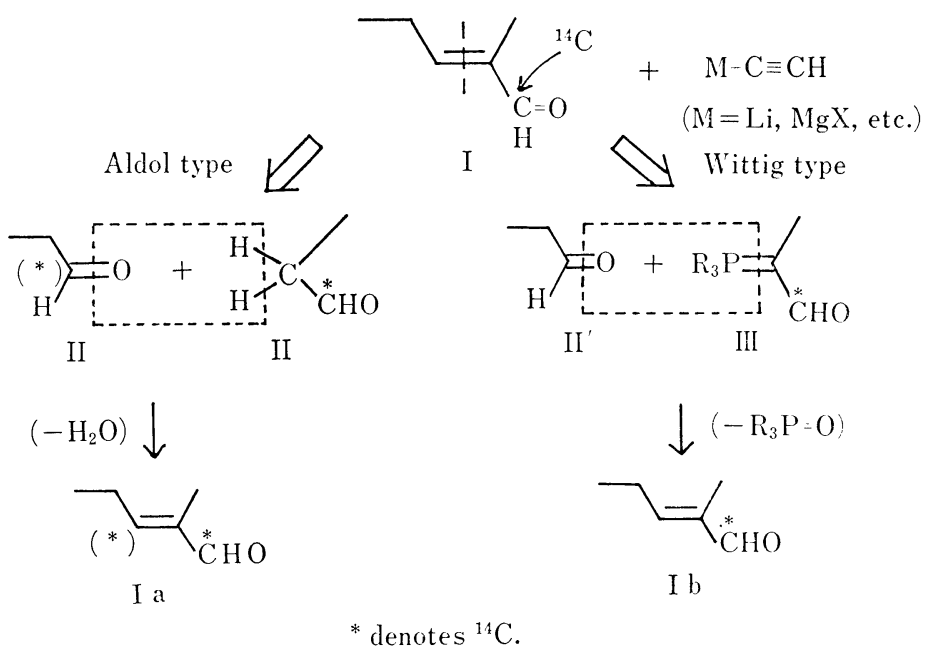

Fig. 1 Retrosynthetic analysis of empenthrin for ${ }^{14} \mathrm{C}$-labeling at the alcoholic $\mathrm{C}-1$ position.

through oxidative cleavage of the double bond. Therefore, we planned an alternative approach involving Wittig-type olefinations to the regioselectively labeled aldehyde (Ib). Previously, Trippett and Walker ${ }^{5)}$ reported that ethyl formate acted on an ethylidenephosphorane to yield the $\alpha$-formylated product, which afforded the unsaturated aldehyde of the type $\mathrm{R} \cdot \mathrm{CH}: \mathrm{C}$ (Me) $\cdot \mathrm{CHO}$ by reacting with aldehydes $\mathrm{RCHO}$ in good yields. After comparison with other synthetic metohds of $\alpha, \beta$-unsaturated aldehydes such as that of Corey et al. ${ }^{6}$, we decided to apply this method to the present synthesis with some modification. The total synthesis of $(1 R)$ cis- and $(1 R)$-trans-[pentenyl-1-14C]empenthrins (1a and 1b) was carried out according to the reaction seqeunce illustrated in Fig. 2.

${ }^{14} \mathrm{C}$-Formylation of ethylidenetriphenylphosphorane, which was conventionally prepared from the corresponding phosphonium salt, with ethyl $\left[{ }^{14} \mathrm{C}\right]$ formate $(2)$ gave $1-\left[{ }^{14} \mathrm{C}\right]$ formylethylidenetriphenylphosphorane (3) in $63 \%$ yield after purification by selective extraction. Wittig reaction of the $\left.{ }^{[14} \mathrm{C}\right]$ phosphorane (3) with a large excess of freshly distilled propanal proceeded under benzene reflux condition to afford 2-methyl-2-[1- $\left.{ }^{14} \mathrm{C}\right]$ pentenal (4) quantitatively. Based on the RGC analysis, the unsaturated aldehyde (4) obtained was chemically contaminated with the materials originating from non-radioactive propanal. Purification of 4 by a conventional method such as reduced distillation or column chromatography was, however, apparently impractical because of its high volatility. Therefore, we planned to purify 4 after derivatization to a proper non-volatile compound. Our initial attempts involving familiar methods such as bisulfite treatment ${ }^{7)}$ and Shiffbase preparation ${ }^{8)}$ were unsuccessful. On the other hand, derivatization of 4 to a certain imidazolidine $^{9)}$ gave a hopeful result. Thus, the crude unsaturated aldehyde (4) was allowed to react with $N, N^{\prime}$-diphenylethylenediamine in the presence of an acid catalyst to afford pure 2-(1-methyl-1-[1-14C]butenyl) -1,3-diphenylimidazolidine $(5)$ in $76 \%$ radiochemical yield after 


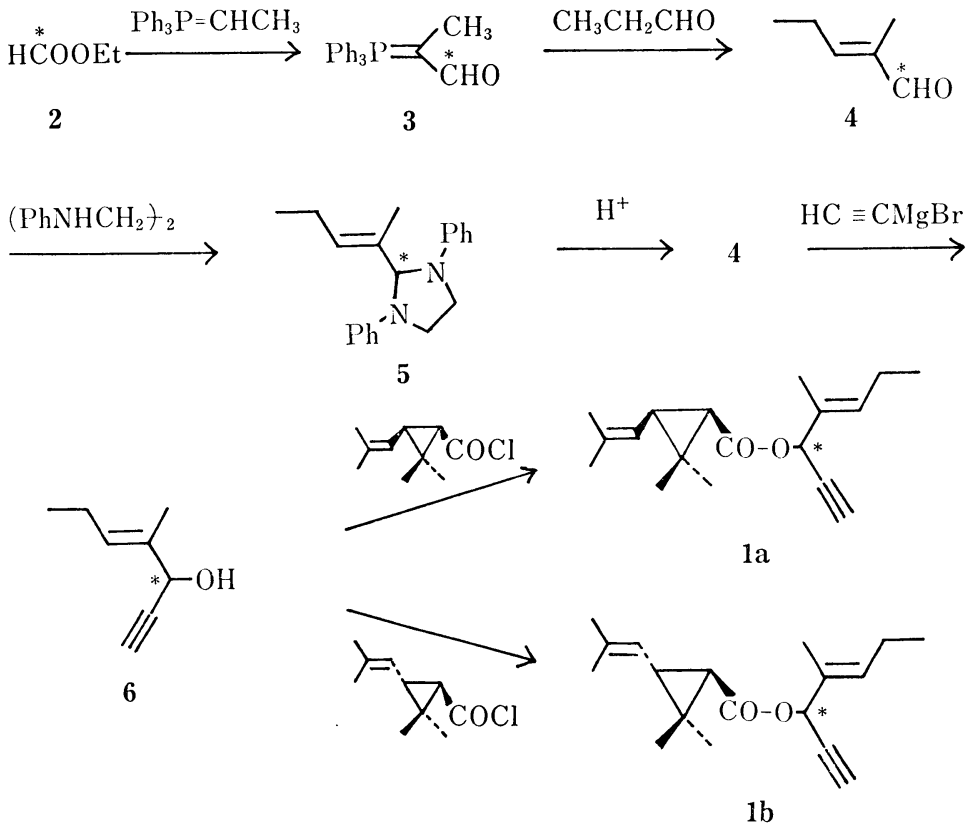

Fig. 2 Synthesis of $(1 R)$-cis- and $(1 R)$-trans $-\left[\right.$ penty $\left.1-1-{ }^{14} \mathrm{C}\right]$ empenthrins.

crystallization from methanol. Treatment of the purified imidazolidine (5) with diluted hydrochloric acid revived the aldehyde (4) with the purity greater than $98 \%$ in $86 \%$ yield. The NMR study on 4 suggested that the Wittig reaction of the formylated phosphorane (3) with propanal proceeded stereoselectively to yield only the $E$ isomer ${ }^{10)}$, by good fortune, similarly to the aldol condensation of propanal alone. The revived $\left[{ }^{14} \mathrm{C}\right]$ aldehyde (4) was allowed to undergo the action of ethynylmagnesium bromide, which was prepared by exchange reaction between acetylene and ethylmagnesium bromide at $-20{ }^{\circ} \mathrm{C}$, to give 1-ethynyl-2-methyl-2-[1- $\left.{ }^{14} \mathrm{C}\right]-$ pentenol (6) with the purity around $90 \%$ in $91 \%$ yield after usual work-up. The RGC analysis showed that the ethynyl alcohol (6) was a 99.2:0.8 mixture of the $E$ and $Z$ isomers. The carbinol (6) was, without further purification, condensed with $(1 R)$-cis- and $(1 R)$-transchrysanthemoyl chlorides in the presence of pyridine to give quantitatively two optically active [pentenyl-1- ${ }^{14} \mathrm{C}$ ]empenthrins ( $\mathbf{1 a}$ and $\mathbf{1 b}$ ), which were chromatographed on florisil with hexane to afford radiochemically and chemically pure 1a and 1b in 67 and $69 \%$ yields, respec- tively, from 6. The specific activity was found to be $966 \mathrm{MBq} / \mathrm{mmol}$.

\section{Experimental}

Radio-thin layer chromatography (RTLC) was carried out on a Silica Gel $60 \mathrm{~F}_{254}$ plate (Merck), except for the imidazolidine (5) on an Aluminium Oxide $60 \mathrm{~F}_{254}$ plate (Type E, Merck), and the radioactivity on the plate was determined by a JTC-601 Radiochromanyzer (Aloka, Japan). Radio-gas chromatography (RGC) was performed on a Yanaco G-180 gas chromatograph (detector FID) (Yanagimoto Co., Ltd., Japan) equipped with a RD-4 gas-flow GM counter (Aloka). A glass column ( $3 \mathrm{~mm}$ ID $\times$ $2.1 \mathrm{~m}$ ) packed with $10 \%$ FFAP on Uniport HP (60 - 80 mesh) (Nishio Kogyo Co., Ltd.) was used for the analysis of $(E)$-2-methyl-2$\left[1-{ }^{14} C\right]$ pentenal $(4)$ and $(E)$-1-ethynyl-2-methyl$2-\left[1-{ }^{14} \mathrm{C}\right]$ pentenol (6). Operating condition for the aldehyde (4): column temperature $70{ }^{\circ} \mathrm{C}$, carrier gas $\mathrm{He} 50 \mathrm{ml} / \mathrm{min}$; retention time 11.0 min. Operating condition for the carbinol (6): column temperature $140{ }^{\circ} \mathrm{C}$, carrier gas $\mathrm{He}$ $50 \mathrm{ml} / \mathrm{min}$; retention time $13.0 \mathrm{~min}$ (the $Z$ isomer $11.8 \mathrm{~min}$ ). Another glass column ( $3 \mathrm{~mm}$ 
ID $\times 1.1 \mathrm{~m})$ packed with $2 \%$ DEGS on Chromosorb W AW DMCS (60-80 mesh) (Nishio Kogyo Co.) was used for the analyses of $(1 R)$ cis- and (1R)-trans- [pentenyl-1-14C]empenthrins (1a and 1b). Operating condition: column temperature $110{ }^{\circ} \mathrm{C}$, carrier gas $\mathrm{He} 50 \mathrm{ml} / \mathrm{min}$; retention time $13.2 \mathrm{~min}$. Radio-high performance liquid chromatography (RHPLC) was conducted at ambient temperature on a LC-3A high performance liquid chromatograph (Shimadzu Co., Ltd., Japan) equipped with a SPD-2A UV detector (Shimadzu Co.) and a RLC-551 Radioanalyzer (Aloka). A stainless steel column $(6 \mathrm{~mm}$ ID $\times 15 \mathrm{~cm})$ packed with YMC-GEL ODS (A type, $5 \mu \mathrm{m}$ ) (Yamamura Chemical Co., Ltd.) was used for the analyses of the imidazolidine (5) and ${ }^{14} \mathrm{C}$-labeled empenthrins $(\mathbf{1 a}, \mathbf{1 b})$. Operating condition for 5:mobile phase methanol/water $=4 / 1(\mathrm{v} / \mathrm{v})$, flow rate $1.0 \mathrm{ml} / \mathrm{min}$, UV $254 \mathrm{~nm}$; retention time $16.8 \mathrm{~min}$. Operating condition for 1a and 1b: mobile phase acetonitrile/water = $3 / 1(\mathrm{v} / \mathrm{v})$, flow rate $1.0 \mathrm{ml} / \mathrm{min}$, UV $240 \mathrm{~nm}$; retention times $20.0 \mathrm{~min}$ (1a) and $21.9 \mathrm{~min}(\mathbf{1 b})$. An infrared spectrum (IR) was measured in nujol on a IR-810 grating infrared spectrometer (JASCO Co., Ltd., Japan), and the characteristic streching absorptions $\left(\nu_{\max }\right)$ were described in $\mathrm{cm}^{-1}$. A proton nuclear magnetic resonance spectrum (NMR) was determined in chloroform- $d$ on a H-90 NMR spectrometer (Hitachi Co., Ltd., Japan), and the chemical shifts $(\delta)$ were quoted in $\mathrm{ppm}$ downfield from tetramethylsilane as the internal standard. A mass spectrum (MS) was measured by a DF/GC/MS M-80 mass spectrometer equipped with a DPS M-003 computed system (inlet system DI or $\mathrm{GC}$; ionization mode $\mathrm{EI}, 70$ or $20 \mathrm{eV}$ ) (Hitachi Co.).

Radioactivity was determined by a TRI-CARB 460 liquid scintillation counter (Packard Instrument Co., USA) by using diluted Permafluor I (Packard) as the counting medium.

\section{$1-\left[{ }^{14} \mathrm{C}\right]$ Formylethylidenetriphenylphosphorane}

To a stirred suspension of ethyltriphenylphosphonium iodide $(5.98 \mathrm{~g}, 14.3 \mathrm{mmol})$ in anhydrous ether $(30 \mathrm{ml})$ was added a solution of $n$-butyl lithium in hexane $(1.16 \mathrm{M}, 13.5 \mathrm{ml}$,
$15.7 \mathrm{mmol}$ ), and the mixture was stirred under dry nitrogen stream at room temperature for $2 \mathrm{~h}$ to prepare ethylidenetriphenylphosphorane in situ. To this solution of the phosphorane was added a solution of ethyl $\left[{ }^{14} \mathrm{C}\right]$ formate (2) (7.40 GBq, $529 \mathrm{mg}, 7.14 \mathrm{mmol}$; purchased from Amersham International plc) in anhydrous ether $(10 \mathrm{ml})$, and the resulting mixture was stirred at the same temperature for $1.5 \mathrm{~h}$. After dilution with $5 \%$ hydrochloric acid, the mixture was washed with ether. The aqueous layer was carefully neutralized with sodium carbonate and extracted with benzene. Evaporation of the solvent gave the ${ }^{14} \mathrm{C}$-formylated phosphorane (3) (4.63 GBq, 62.5\%) as a colorless solid; the purity $97 \%$ on RTLC (chloroform/methanol=6/1 v/v, $R_{\mathrm{f}} \quad 0.35$ ). NMR $(\delta, \mathrm{ppm}): 1.86(3 \mathrm{H}, \mathrm{d}, J=14 \mathrm{~Hz}$, methyl $), 7.20-7.80(15 \mathrm{H}, \mathrm{m}$, phenyl $), 8.04$ (1H, d, $J=4 \mathrm{~Hz}$, formyl). IR $\left(\nu_{\max }, \mathrm{cm}^{-1}\right)$ : $1560(\mathrm{C}=\mathrm{O})$. $\mathrm{MS}(\mathrm{m} / z): 318\left(\mathrm{M}^{+}\right), 317(\mathrm{bp})$, $262,183$.

\section{(E) -2-Methyl-2-[1-14 C]pentenal (4)}

A mixture of the phosphorane (3) $(4.26 \mathrm{GBq}$, $1.66 \mathrm{~g}, 5.22 \mathrm{mmol})$ and freshly distilled propanal $(606 \mathrm{mg}, 10.4 \mathrm{mmol})$ in benzene $(10 \mathrm{ml})$ was stirred with reflux for $7 \mathrm{~h}$ under nitrogen atmosphere. After addition of propanal $(1.75 \mathrm{~g}$, $30.0 \mathrm{mmol}$ ), the mixture was refluxed for further $6 \mathrm{~h}$. Then the mixture was cooled, diluted with ether, and washed with water and brine. After drying over anhydrous sodium sulfate, the ethereal solution was condensed under atmospheric pressure to give the crude $\alpha, \beta$-unsaturated aldehyde (4) $(4.14 \mathrm{GBq}, 97.4 \%)$; the radiochemical purity $97 \%$ on RTLC (chloroform $/$ methanol $=20 / 1 \mathrm{v} / \mathrm{v}, R_{\mathrm{f}} 0.65$ ) and RGC.

(E)-2-(1-Methyl-1-[1-14C]butenyl)-1,3-diphenylimidazolidine (5)

To a stirred solution of the crude aldehyde (4) $(4.14 \mathrm{GBq}, 499 \mathrm{mg}, 5.08 \mathrm{mmol})$ and $50 \%$ acetic acid $(0.1 \mathrm{ml})$ in methanol $(12 \mathrm{ml})$ were added $N, N^{\prime}$-diphenylethylenediamine $\quad(2.24 \mathrm{~g}$, $10.6 \mathrm{mmol}$ ) and a few drops of phosphoric acid. After seeding a small amount of the unlabeled imidazolidine crystals, the solution was stirred at $6{ }^{\circ} \mathrm{C}$ for $20 \mathrm{~h}$. The precipitate 
formed was filtered, washed with chilled methanol $(5 \mathrm{ml})$ and dried under reduced pressure to give the ${ }^{14} \mathrm{C}$-labeled imidazolidine (5) (3.14 GBq, $75.8 \%$ ) as colorless needles; the purity more than $98 \%$ on RTLC (aluminium oxide, benzene/ethyl acetate $\left.=4 / 1 \mathrm{v} / \mathrm{v}, R_{\mathrm{f}} 0.54\right)$ and RHPLC. $\operatorname{NMR}(\delta, \mathrm{ppm}): 0.98(3 \mathrm{H}, \mathrm{t}, J=7 \mathrm{~Hz}$, $\left.-\mathrm{CH}_{2} \mathrm{CH}_{3}\right), 1.32\left(3 \mathrm{H}, \mathrm{s},=\mathrm{C}\left(\mathrm{CH}_{3}\right) \mathrm{CH}<\right), 1.90$ (2H, m, $\left.\mathrm{CH}_{3} \mathrm{CH}_{2} \mathrm{CH}=\right), 3.74\left(4 \mathrm{H}, \mathrm{s},-\mathrm{CH}_{2} \mathrm{CH}_{2}-\right)$, $5.40\left(1 \mathrm{H}, \mathrm{s},=\mathrm{C}\left(\mathrm{CH}_{3}\right) \mathrm{CH}<\right), 5.85(1 \mathrm{H}, \mathrm{t}, J=7$ $\left.\mathrm{Hz},-\mathrm{CH}_{2} \mathrm{CH}=\right), 6.68-7.35(10 \mathrm{H}, \mathrm{m}$, phenyl). MS $(m / z): 292\left(\mathbf{M}^{+}\right), 263,223(\mathrm{bp})$.

Decomposition of the imidazolidine (5) to revive the aldehyde (4)

A mixture of the imidazolidine (5) (3.14 GBq, $923 \mathrm{mg}, 3.16 \mathrm{mmol}$ ) and $5 \%$ hydrochloric acid $(30 \mathrm{ml})$ was stirred at room temperature for $3 \mathrm{~h}$, and extracted with ether. The ethereal extract was washed with water and brine, successively, and dried over anhydrous sodium sulfate. Removal of the solvent under atmospheric pressure gave the aldehyde (4) $(2.70$ $\mathrm{GBq}, 85.9 \%$ ); the chemical and radiochemical purities greater than $98 \%$ on RTLC and RGC quoted above. NMR $(\delta, \mathrm{ppm}): 1.10(3 \mathrm{H}, \mathrm{t}$, $\left.J=6 \mathrm{~Hz},-\mathrm{CH}_{2} \mathrm{CH}_{3}\right), 1.71\left(3 \mathrm{H}, \mathrm{s},=\mathrm{C}(\mathrm{CHO}) \mathrm{C}_{3}\right)$, $2.21-2.54\left(2 \mathrm{H}, \mathrm{m}, \mathrm{CH}_{3} \mathrm{CH}_{2} \mathrm{CH}=\right), 6.47(1 \mathrm{H}, \mathrm{t}$, $J=7 \mathrm{~Hz},=\mathrm{CH}-), 9.40(1 \mathrm{H}, \mathrm{s},-\mathrm{CHO})$.

\section{(E)-1-Ethynyl-2-methyl-2-[1-14C]pentenol (6)}

To a saturated solution of acetylene in anhydrous tetrahydrofuran $(10 \mathrm{ml})$ was added at $-20^{\circ} \mathrm{C}$ a solution of ethylmagnesium bromide in tetrahydrofuran $(2.0 \mathrm{M}, 5.0 \mathrm{ml}, 10.0$ $\mathrm{mmol}$ ), and the mixture was stirred at the same temperature for $1 \mathrm{~h}$ under dry nitrogen atmosphere to prepare ethynylmagnesium bromide in situ. To this mixture was added a solution of the aldehyde (4) (2.70 GBq, $259 \mathrm{mg}, 2.60 \mathrm{mmol})$ in tetrahydrofuran $(5 \mathrm{ml})$, and the resulting mixture was stirred at room temperature for 1.5 h. After decomposition with chilled 5\% sulfuric acid the mixture was extracted with ether. The extract was washed with brine and dried over anhydrous sodium sulfate. Evaporation of the solvent gave the carbinol (6) $(2.35 \mathrm{GBq}, 90.8$ $\%)$; the purity $87 \%$ on RTLC (chloroform, $\left.R_{\mathrm{f}} 0.26\right)$ and $98 \%$ on $\operatorname{RGC~}(E / Z=99.2 / 0.8)$.
NMR $\left(\delta\right.$, ppm): $0.96\left(3 \mathrm{H}, \mathrm{t}, J=7 \mathrm{~Hz},-\mathrm{CH}_{2}\right.$ $\left.\mathrm{CH}_{3}\right), 1.71\left(3 \mathrm{H}, \mathrm{s}, \mathrm{CH}_{3}-\mathrm{C}(=\mathrm{C}<)-\right), 1.84-2.23$ $\left(3 \mathrm{H}, \mathrm{m}, \mathrm{CH}_{3} \underline{\mathrm{CH}}_{2} \mathrm{CH}=\right.$ and $\left.>\mathrm{C} \underline{\mathrm{H}}-\mathrm{OH}\right), 2.52(1 \mathrm{H}$, $\mathrm{d}, \quad J=3 \mathrm{~Hz},-\mathrm{C} \equiv \mathrm{CH}), 4.74(1 \mathrm{H}, \mathrm{d}, J=3 \mathrm{~Hz}$, $>\mathrm{CH}-\mathrm{OH}), 5.62(1 \mathrm{H}, \mathrm{t}, 7 \mathrm{~Hz},-\mathrm{CH}=\mathrm{C}<)$. MS $(m / z): 124\left(\mathrm{M}^{+}\right), 109,95(\mathrm{bp})$.

\section{(1R)-cis-[pentenyl-1-14 C]Empenthrin (1a)}

A mixture of $(1 R)$-cis-chrysanthemic acid (841 mg, $5.00 \mathrm{mmol}, \quad 99.5 \% \quad(1 R)$-cis) and oxalyl chloride $(2.53 \mathrm{~g}, 20.0 \mathrm{mmol})$ in anhydrous hexane $(5 \mathrm{ml})$ was stirred at room temperature for $2 \mathrm{~h}$ and evaporated to give an oily residue of $(1 R)$-cis-chrysanthemoyl chloride, which was dissolved in anhydrous benzene $(5.0 \mathrm{ml})$. A portion of this solution $(2.0 \mathrm{ml}$, $1.0 \mathrm{M}$, acid chloride $2.0 \mathrm{mmol}$ ) was mixed with a solution of the carbinol (6) (1.18 GBq, $179 \mathrm{mg}, \quad 1.44 \mathrm{mmol}$ ) in anhydrous benzene $(5 \mathrm{ml})$. After addition of anhydrous pyridine (198 $\mathrm{mg}, 2.50 \mathrm{mmol}$ ), the mixture was stirred at room temperature for $3 \mathrm{~h}$. Then small amounts of the acid chloride solution $(0.5 \mathrm{ml}$, $0.5 \mathrm{mmol}$ ) and pyridine (32 $\mathrm{mg}, 0.4 \mathrm{mmol}$ ) were added, and the mixture was stirred for additional $1 \mathrm{~h}$ to complete the esterification. The resulting mixture was diluted with chilled $5 \%$ hydrochloric acid and extracted with ether. The extract was washed with $1 \%$ sodium hydroxide, water and brine, successively, dried over anhydrous sodium sulfate and evaporated to give a residue, which was chromatographed on Florisil (Wako Pure Chemical Industries, Ltd.) with hexane. Evaporation of the main fractions gave the ester (1a) (784 MBq, $224 \mathrm{mg}, 66.7 \%$ ); the purity more than $98 \%$ on RTLC (benzene, $R_{\mathrm{f}} 0.52$; hexane/ethyl acetate $=3 / 1 \mathrm{v} / \mathrm{v}, R_{\mathrm{f}}$ 0.57), RGC and RHPLC. $\operatorname{NMR}(\delta, \mathrm{ppm})$ : $0.96\left(3 \mathrm{H}, \mathrm{t}, J=8 \mathrm{~Hz},-\mathrm{CH}_{2} \mathrm{CH}_{3}\right), 1.17,1.20$ and $1.23(6 \mathrm{H}, 3 \mathrm{~s}$, cyclopropyl methyls $), 1.66(3 \mathrm{H}, \mathrm{s}$, $\left.\mathrm{C}=\mathrm{C}\left(\mathrm{CH}_{3}\right) \mathrm{CH}\left(\mathrm{O}_{-}\right)-\right), \quad 1.70 \quad\left(6 \mathrm{H}, \mathrm{s}, \mathrm{C}=\mathrm{C}\left(\mathrm{CH}_{3}\right)_{2}\right)$, 1.54-2.20 $\left(5 \mathrm{H}, \mathrm{m},-\mathrm{CH}_{2} \mathrm{CH}_{3},>\mathrm{CH}-\mathrm{O}-\right.$ and cyclopropyl 1, $3 \mathrm{H}), 2.47(1 \mathrm{H}, \mathrm{m}, \mathrm{HC} \equiv \mathrm{C}-), 5.35$ $\left(1 \mathrm{H}, \mathrm{d}, J=8 \mathrm{~Hz},\left(\mathrm{CH}_{3}\right)_{2} \mathrm{C}=\mathrm{CH}-\right), 5.62(1 \mathrm{H}, \mathrm{t}$, $\left.J=7 \mathrm{~Hz}, \quad-\mathrm{CH}_{2} \mathrm{CH}=\mathrm{C}\left(\mathrm{CH}_{3}\right)-\right)$. MS $(\mathrm{m} / \mathrm{z}): 274$ $\left(\mathrm{M}^{+}\right)$, 204, 123 (bp).

(1R)-trans-[pentenyl-1- $\left.{ }^{14} \mathrm{C}\right]$ Empenthrin (1b) According to the same manner as described 
above, the carbinol (6) $(1.18 \mathrm{GBq}, 179 \mathrm{mg}$, $1.44 \mathrm{mmol}$ ) was esterified with the acid chloride prepared from (1R)-trans-chrysanthemic acid (99.3\% (1R)-trans), and the crude product was purified by Florisil column chromatography to give the optically active ester (1b) (810 MBq, $231 \mathrm{mg}, 68.9 \%$ ); the purity more than $98 \%$ on RTLC, RGC and RHPLC. NMR ( $\delta, \mathrm{ppm})$ : $0.98\left(3 \mathrm{H}, \mathrm{t}, J=8 \mathrm{~Hz},-\mathrm{CH}_{2} \mathrm{CH}_{3}\right), 1.12(3 \mathrm{H}, \mathrm{s}$, cyclopropyl methyl), 1.24 and $1.28(3 \mathrm{H}, 2 \mathrm{~s}$, cyclopropyl methyl), 1.69 (9H, bs, $-\mathrm{CH}=\mathrm{C}$ $\left(\mathrm{CH}_{3}\right)_{2}$ and $\left.-\mathrm{C}\left(\mathrm{CH}_{3}\right)=\right), 0.80-2.40(5 \mathrm{H}, \mathrm{m},=\mathrm{CH}$ $-\mathrm{CH}_{2} \mathrm{CH}_{3},>\mathrm{CH}-\mathrm{O}$ and cyclopropyl $1,3 \mathrm{H}$ ), $2.50(1 \mathrm{H}, \mathrm{d}, J=3 \mathrm{~Hz},-\mathrm{C} \equiv \mathrm{CH}), 4.91(1 \mathrm{H}, \mathrm{d}$, $\left.J=8 \mathrm{~Hz},\left(\mathrm{CH}_{3}\right)_{2} \mathrm{C}=\mathrm{CH}-\right), 5.71(1 \mathrm{H}, \mathrm{t}, J=7 \mathrm{~Hz}$, $\left.-\mathrm{CH}_{2} \mathrm{CH}=\mathrm{C}\left(\mathrm{CH}_{3}\right)_{2}\right)$. MS $(\mathrm{m} / z): 274\left(\mathrm{M}^{+}\right), 204$, 123 (bp).

\section{References}

1) Kitamura, S., Itaya, N., Okuno, Y., Ohono, N., Hirano, M., Matsuo, T., Mizutani, T. and Takeda, H.: Japan Patent Koukoku, 55-42045 (1980)
2) Matsuo, T., Nishioka, T., Hirano, M., Suzuki, Y., Tsushima, K., Itaya, N. and Yoshioka, H.: Pesti. Sci., 11, 202 (1980)

3) Okuno, Y., Matsuo, M. and Kitamura, S.: Sumitomo-Kagaku-Shi, 1983-II, 12 (1983)

4) Hirano, M., Yano, T., Matsuo, N., Kitamura, S., Nishioka, T. and Fujita, Y.: SP World, 10, 19 (1988)

5) Trippett, S. and Walker, D. M.: J. Chem. Soc., 1226 (1961)

6) Corey, E. J., Enders, D. and Bock, M. G.: Tetrahedron Lett., 1976, 7

7) “Org. Syn.", Coll. Vol. II, 1950, 323, John Wiley \& Sons, Inc.

8) Fritsch, W., Schmidt-Thome, J., Rushing, H. and Haeda, W.: Chem. Ber., 96, 68 (1963)

9) Wanzlich, H.-W. and Hochel, W.: ibid., 86, 1463 (1953)

10) Chan, K. C., Jewell, R. A., Mitting, W. H. and Rapoport, H.: J. Org. Chem., 33, 3382 (1968)

\author{
新規衣料用防虫剂エムペンスリンの位置選択的 \\ ${ }^{14} \mathrm{C}$ 標識体の立体選択的合成 \\ 金丸 博，川原一夫，西岡和彦 \\ 住方化学工業㑣宝塚総合研究所安全性研究所 \\ 665 兵庫県宝塚市高司 4-2-1
}

\footnotetext{
エムペンスリンの立体異性体 2 種の特異なアルコール部分に関する代謝研究を行うために, それ らの位置選択的 ${ }^{14} \mathrm{C}$ 標識体 $(\mathbf{1} \mathbf{a}, \mathbf{1} \mathbf{b})$ を立体選択的に合成した。すなおち， $\left[{ }^{14} \mathrm{C}\right]$ キ酸エチル $(\mathbf{2})$ から調製したホルミルホスホラン（3）とプロパナールとの Wittig 反応をキーステップとする立体 選択的合成経路に従い，通算収率36\%で所期のアルコール(6)を合成し，これを 2 種の光学活性菊 酸と縮合することにより $\mathbf{1} \mathbf{a}, \mathbf{1} \mathbf{b}$ を調製した。
} 